\title{
The Canadian commercial forestry perspective on certification: National survey results
}

\author{
by Bill Wilson ${ }^{1}$, Takuya Takahashi ${ }^{2}$ and Ilan Vertinsky ${ }^{3}$
}

Certification has rather quickly emerged to become an important element within the response amalgam to public concerns about the sustainability of commercial forestry. This paper presents the results of a national survey designed to examine the attitudes of Canadian forest companies toward the various certification vehicles and the underlying basis for those attitudes. Included are the ISO 14001 , CSA, FSC and FORESTCARE vehicles. The results, which include responses from 117 companies, confirm a recognized need to achieve forest certification and that the appropriate certification vehicle remains unsettled. It is also clear that the forest industry does not expect a price premium to accrue from any of the vehicles. Instead, the main reason for certification is to secure continued access to public forest lands through improved public acceptance of forest management and reduced pressure from environmental groups.

Key words: forest certification, sustainable forest management, criteria and indicators

La certification a progressé plutôt rapidement pour devenir un élément important de l'amalgame des réponses relatives aux inquiétudes du public en matière de durabilité de la foresterie commerciale. Cet article présente les résultats d'un sondage national conçu pour examiner les attitudes des compagnies forestières canadiennes envers les différents processus de certification et les fondements de ces attitudes. Les processus ISO 14001, CSA, FSC et FORESTCARE sont étudiés. Les résultats, qui proviennent des réponses de 117 compagnies, confirment un besoin reconnu d'obtenir une certification forestière et que le processus approprié de certification reste à définir. Il est également évident que l'industrie forestière ne s'attend pas à obtenir une majoration de ses prix suite à ces processus. Au contraire, la principale raison pour obtenir une certification est de maintenir un accès continu aux territoires forestiers publics par l'entremise d'une acceptation plus grande du public de l'aménagement forestier et de la réduction des pressions exercées par les groupes environnementaux.

Mots-clés : certification forestière, aménagement forestier durable, critères et indicateurs

\section{Introduction}

Increasing rates of global deforestation, improved information and ready access to this information combined with a strong emergence of environmental values in many jurisdictions to give concerns about forest sustainability a high priority in the public agenda. Environmental non-governmental organizations (ENGOs), the forest industry, and governments have taken a wide

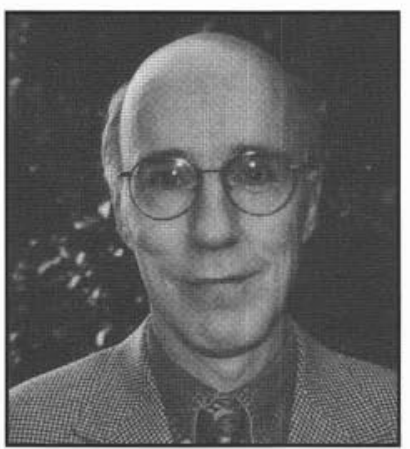

Bill Wilson range of approaches to addressing these concerns. The approaches include intensive regulation of forestry practices, calls for consumer boycotts of products from "unsustainable" forests, and media campaigns showcasing the impacts of select aspects of commercial forestry (e.g., clearcuts, habitat loss; Cabarle and Heiner 1994, Stanbury et al. 1995, Wilson and Wang 1999). One recent and promising approach is the certification of forests and labelling of forest products to demonstrate compliance

${ }^{1}$ Director, Industry, Trade and Economics, Pacific Forestry Centre, Canadaian Forest service, 506 West Burnside Road, Victoria, BC V8Z 1M5. E-mail: bwilson@pfc.forestry.ca

${ }^{2}$ Graduate student, Forest Economics and Policy Analysis Research Unit, University of British Columbia, 2424 Main Mall, Vancouver, BC V6T 1 Z4.

${ }^{3}$ Professor and Director at the Forest Economics and Policy Analysis Research Unit, University of British Columbia, 2424 Main Mall, Vancouver, BC V6T 1 Z4.

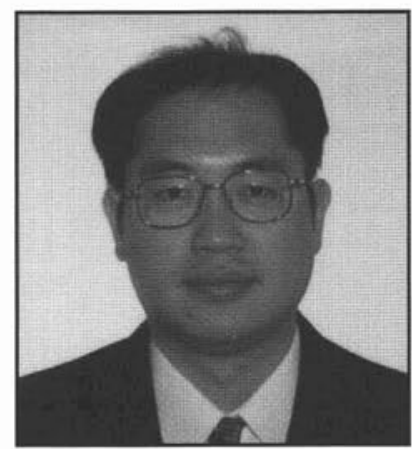

Takuya Takahashi

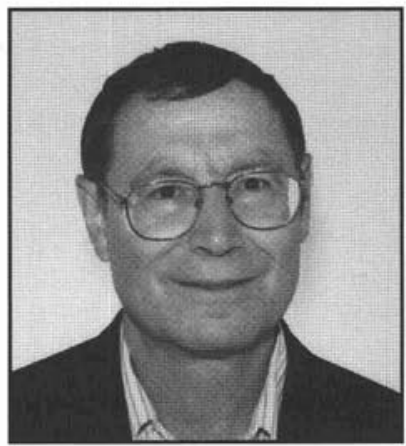

Ilan Vertinsky with certain standards (Elliot 1996, Viana et al. 1996). This paper provides an overview of a Canadian forest industry survey on the certification process.

\section{Forest Certification}

Forest certification has its roots in the perceived failure of the international community to respond to rapid tropical deforestation and forest degradation during the 1980s (Vogt et al. 1999, Hansen and Fletcher 2000). However, the watershed 1992 United Nations Conference on the Environment and Development (AKA the Rio Earth Summit) served to draw into question forest management in developed countries. The Summit subsequently led to development of the initial sets of principles, criteria and indicators (C\&I), the key ingredients to an operational basis for sustainable forest management and an evaluation pursuant to forest certification. 
The two common certification approaches are "systems-based," where the company must have management systems to recognize, monitor and improve environmental impacts; and "performance-based," which requires the company to meet prescribed performance standards. Wood product certification or eco-labelling involves tracing the wood harvested in certified forests through all stages of transport, processing and marketing of the finished product - what is known as a "chain-of- custody" inspection (Crossley 1996, Viana et al.1996). Forest certification can take three basic forms. First-party involves an internal assessment or self-audit; second-party is assessment by a customer or industry organization/association; and third-party is an independent audit.

This survey focused on four certification vehicles, namely: 1) the Forest Stewardship Council (FSC); 2) Canadian Standards Association (CSA); 3) International Organization for Standardization's ISO $14001^{4}$; and 4) FORESTCARE by the Alberta Forest Products Association. Of these vehicles, only the FSC currently includes eco-labelled products (see Table 1). The FSC is an international organization comprised of environmental, social and industry interests. In Canada, three FSC regional standards are actively under development - the Acadian region, the Great Lakes-St. Lawrence (Ontario), and British Columbia (both interior and coastal; see http://www.fscoax.org or http://www.web.net/fscca/). A boreal zone standards committee is being struck.

The CSA is Canada's national standard-setting body. In 1994, the CSA technical committee drafted national standards for sustainable forest management (SFM). Consultations with the public and environmental groups followed (although many of the participating ENGOs withdrew), producing an SFM package approved by the Standards Council of Canada in 1996. Among other things, the CSA SFM requires independent audit, compliance with government regulations, and a commitment to continuous improvement guided by the C\&I endorsed by the Canadian Council of Forest Ministers. These C\&I have their roots in the Montreal Process (http://www.mpci.org). The CSA SFM is an amalgam of the ISO 14001 systems-based and a C\&I performance-based approaches. The vehicle does not have an eco-label (http://www.sfms.co).

In 1996, the ISO introduced ISO 14001 for the certification of environmental management systems for any enterprise willing to improve its environmental management. The standard requires respect of laws and regulations, commitment to continuous improvement and training of all relevant personnel. ISO has produced a bridging document in an effort to promote the use of ISO 14001 in forestry. The ISO certification is a generic, system-based vehicle which pointedly excludes any "green" claims (see Tibor 1996, Tibor and Feldman 1997).

The Alberta Forest Products Association, an industry association, introduced FORESTCARE in 1991 and ratified the audit program in 1994. FORESTCARE covers both forest and mill operations. An audit team grades the performance of participating firms' according to the program's Code of Practices (http://www.abforestprod.org).

Two important international certification vehicles that were not addressed in the survey are the Sustainable Forestry Initiative

\begin{tabular}{|c|c|c|c|}
\hline Vehicle & Characteristics & Application & Eco-label \\
\hline ISO 14001 & $\begin{array}{l}\text { Optional } 3^{\text {rd }} \text { party audited; } \\
\text { Systems-based }\end{array}$ & International & No \\
\hline CSA & $\begin{array}{l}3^{\text {rd }} \text { party audited; } \\
\text { Systems and performance-based }\end{array}$ & Canada & No \\
\hline FSC & $\begin{array}{l}3^{\text {rd }} \text { party audited; } \\
\text { Performance-based }\end{array}$ & International & Yes \\
\hline FORESTCARE & $\begin{array}{l}\text { 2nd party audited; } \\
\text { Performance-based }\end{array}$ & Alberta & No \\
\hline
\end{tabular}

Table 2. How familiar are you with the listed certification vehicles? (Scale: No knowledge $=1$, Extremely familiar $=7$ )

\begin{tabular}{lc}
\hline Certification Vehicle & Mean Value \\
\hline ISO 14001 & 4.2 \\
CSA & 4.0 \\
FSC & 3.7 \\
FORESTCARE & 2.8 \\
\hline
\end{tabular}

(SFI) of the American Forest and Paper Association (http://www.afandpa.org) and the Pan European Forest Certification (PEFC) program introduced in 1999 (http://www.pefc.org). Given the significance of the US market, it is encouraging that the SFI vehicle is available to Canadian companies. At a strategic level, the key PEFC contribution is the mutual-recognition of a variety of national and regional certification vehicles in Europe. This is based on adherence to a C\&I package again similar to that developed in the Montreal Process.

\section{Survey Results}

In May-August 1999, the authors conducted a survey on forest certification using a structured questionnaire. The survey population was collected from two industry directories, The Big Book (Random Lengths 1998) and Pulp and Paper Canada Annual Directory (CPPA 1999). Companies with facilities in Canada producing lumber, plywood, veneer, oriented strandboard (OSB) and waferboard, shingles and shakes, and pulp and paper were included in the survey ${ }^{5}$. The questionnaire was sent to 475 senior executives employed at Canadian forest products companies. Follow-up telephone calls were made after the mail-out. The analysis is based on 142 responses (30\% response rate) from 117 different firms.

Survey respondents indicated they were most familiar with the ISO 14001 vehicle and quite familiar with the CSA and FSC schemes (Table 2). Not surprisingly, a majority of the respondents were not familiar with FORESTCARE, a regional industry-run program. When respondents were asked whether they were participating or considering participating in each of the listed certification vehicles, $55 \%$ of the respondents indicated they were either participating in or considering ISO 14001,38\% the CSA and 24\% the FSC vehicles (Table 3). Only 19\% indicated participation or intention to participate in the FORESTCARE program; however, more than $80 \%$ of Alberta respondents indicated participation or intention to participate in FORESTCARE. Forty-two percent of the responding com-

\footnotetext{
${ }^{5}$ Excluded from the sample were pulp and paper manufacturing companies

using only recycled materials as their fiber source.
}

\footnotetext{
${ }^{4}$ In our questions, we specifically limit ISO 14001 certification to the area of forestry. Therefore, the survey does not consider ISO 14001 in other areas, such as processing and transportation.
} 


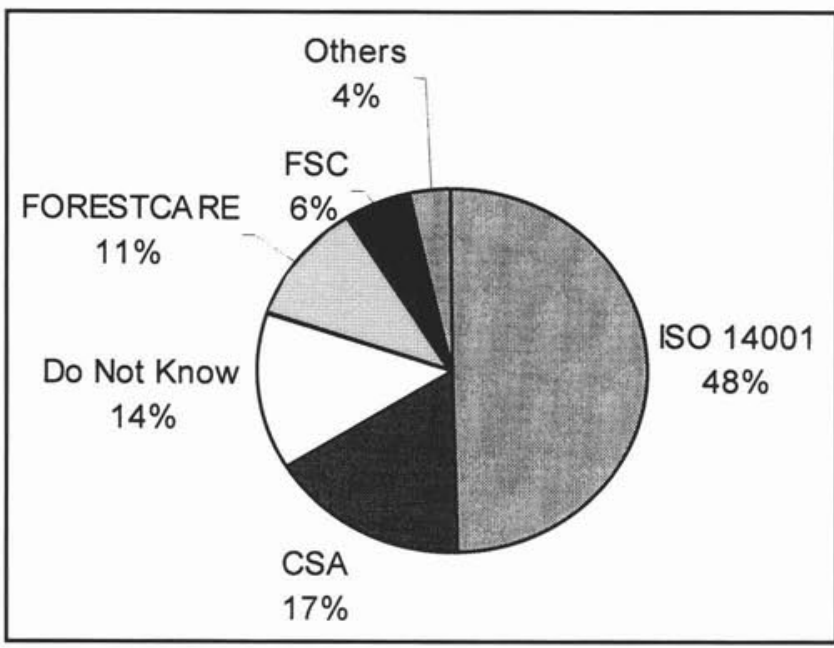

Fig. 2. Select the certification vehicle best matched to your company's needs.

to conflict between certification and government regulatory requirements were all ranked as relatively low disadvantages of certification. Again, FSC was different in that respondents ranked both conflict with government regulation and loss of forest management control relatively high. Lack of customer credibility and small markets were ranked as high disadvantages for FORESTCARE. The availability of accredited certification agencies was ranked the lowest among disadvantages.

\section{Other Questions}

Survey respondents indicated that forestry divisions and top management lead forest certification decisions. We also asked respondents to rate the attitude of various company stakeholders on forest certification. Public relations, top management and marketing divisions were identified as having the most favourable attitude on forest certification. Labour unions were rated as having the least favourable attitude followed closely by shareholders. Despite their relatively positive attitude for certification, public relations and marketing divisions were infrequently selected as the firm's lead in certification. Other results can be obtained in Takahashi et al. (1999).

\section{Conclusions}

Forest certification has the potential to make all sector stakeholders more serious about resource management decisions and seek a balance among the multiple needs of society, ecology and economics. The major benefits associated with certification include improvements in corporate image and credibility, market access and maintenance, and improvements in forest operations, manufacturing and logistics. However, the potential and benefits carry risks as well (Hansen and Fletcher 2000). The risks include stranded investments and market loss should an achieved certification system collapse, the gradual tightening of standards within a certification vehicle, the limits to market acceptance of a particular vehicle, and the loss of corporate credibility resulting from certification disputes resolved in a less than transparent manner.

Although certification is still in its infancy, it is apparent that it will be a factor in global trade, enhancing market share and

Table 5. Assessment of advantages of forest certification vehicles (Will not work $=1$; Will work very well $=7$ )

\begin{tabular}{|c|c|c|c|c|c|c|}
\hline & All Votes & FSC & CSA & ISO14001 & FORESTCARE & Others \\
\hline Advantages & Mean & Mean & Mean & Mean & Mean & Mean \\
\hline Securing public confidence & 5.50 & 6.13 & 5.70 & 5.58 & 5.33 & 4.96 \\
\hline Responding to pressures from ENGOs & 5.27 & 6.25 & 5.23 & 5.33 & 5.27 & 4.76 \\
\hline Securing markets for our products & 4.93 & 5.25 & 5.35 & 5.08 & 3.93 & 4.61 \\
\hline Improving shareholder satisfaction & 4.72 & 4.25 & 4.68 & 4.83 & 4.86 & 4.48 \\
\hline Improving staff morale & 4.00 & 4.19 & 4.00 & 4.06 & 4.21 & 3.64 \\
\hline Improving recreational and landscape features & 3.99 & 5.00 & 3.86 & 3.91 & 4.47 & 3.70 \\
\hline Providing a better habitat for wildlife & 3.97 & 4.63 & 3.77 & 3.88 & 4.47 & 3.88 \\
\hline Ensuring biodiversity & 3.93 & 4.57 & 3.91 & 3.82 & 4.20 & 3.87 \\
\hline Improving access to financial capital & 3.71 & 3.25 & 4.24 & 3.80 & 3.21 & 3.43 \\
\hline Enhancing timber productivity & 3.10 & 3.43 & 2.95 & 3.03 & 3.53 & 3.05 \\
\hline Enabling a price premium & 2.65 & 2.29 & 3.14 & 2.33 & 2.93 & 3.00 \\
\hline Reducing operating costs & 2.63 & 2.00 & 2.52 & 2.87 & 2.80 & 2.17 \\
\hline
\end{tabular}

Table 6. Assessment of forest certification vehicle disadvantages (No problem at all = 1; Very serious problem = 7)

\begin{tabular}{|c|c|c|c|c|c|c|}
\hline & All Votes & FSC & CSA & ISO14001 & FORESTCARE & Others \\
\hline Disadvantages & Mean & Mean & Mean & Mean & Mean & Mean \\
\hline Increased paperwork & 5.12 & 4.75 & 5.04 & 5.00 & 4.80 & 5.84 \\
\hline Direct expense of certification & 4.59 & 3.63 & 4.63 & 4.51 & 3.87 & 5.58 \\
\hline Insufficient price premium for certified products & 4.48 & 4.88 & 5.00 & 4.13 & 4.14 & 5.05 \\
\hline $\begin{array}{l}\text { Increased restrictions on operations } \\
\text { (e.g. on harvest volume) }\end{array}$ & 3.91 & 5.63 & 3.91 & 3.48 & 3.40 & 4.84 \\
\hline Small market for "green" products & 3.85 & 4.00 & 3.80 & 3.53 & 3.92 & 4.75 \\
\hline Low credibility with customers & 3.76 & 2.88 & 3.77 & 3.65 & 3.93 & 4.35 \\
\hline Loss of autonomy and control & 3.58 & 4.00 & 3.74 & 3.23 & 3.43 & 4.36 \\
\hline Conflict with government's regulations & 3.21 & 4.38 & 3.27 & 2.70 & 2.80 & 4.45 \\
\hline Little control over forest management & 3.07 & 2.67 & 2.86 & 2.76 & 2.93 & 4.43 \\
\hline Unavailability of accredited certifiers & 2.76 & 3.38 & 2.82 & 2.39 & 2.38 & 3.84 \\
\hline
\end{tabular}


supporting sector legitimacy. Early adopters may capture a larger market share and by climbing their "learning curves" become more competitive. Clearly, there will be winners and losers in the competition to capture market share. Canada lags behind other major competing regions in the certification of softwood timber products and risks the consequences of further erosion in its competitive position. The struggle will be to maintain market share in American and European markets that are increasingly responsive to environmental issues.

The results of this survey provide primary insight into the motives of firms in their decision-making on whether to certify and in their selection of a specific scheme.

\section{Acknowledgements}

The authors are grateful to the many respondents who took the time to complete the survey. This project was delivered with financial support from the National Centre of Excellence - Suscanable Forest Management Network and the Canadian ForEst Service.

\section{R̃ References}

Cabarle, B. and H. Heiner. 1994. The role of nongovernmental orgaDizations in forestry. J. For. 92(6): 8-12.

స̆Canadian Pulp and Paper Association. 1999. At website 

ثंCrossley, R. 1996. Review of global forest management certificafion initiatives: political and institutional aspects. Second Draft, Doper for the Conference on Social and Political Issues in Certification of Forest Management, Malaysia, May 12-16.
Elliot, C. 1996. Paradigms of forest conservation. Unasylva 47(187): 3-9.

Hansen, E. and R. Fletcher. 2000. Risk and opportunity in relationship to environmental certification. NZ J. For. August: 16-20.

Random Lengths. 1998. The Big Book. Random Lengths Publishing, Ltd. Eugene, Oregon.

Stanbury, W., I. Vertinsky and B. Wilson. 1995. The challenge to Canadian forest products in Europe: managing a complex environmental issue. Canadian Forest Service, Victoria, BC. www.pfc.forestry.ca 102 p.

Takahashi, T., I. Vertinsky, T. Williamson and B. Wilson. 1999. Summary report: Survey of the Canadian commercial forestry perspective on certification. Working Paper 99.05. Canadian Forest Service, Pacific Forestry Centre, Victoria, BC. www.pfc.forestry.ca $18 \mathrm{p}$.

Tibor, T. 1996. ISO 14000 - A Guide to the new environmental management standards. Irwin Professional Publishing, Chicago, Illinois. $230 \mathrm{p}$.

Tibor, T. and I. Feldman. 1997. Implementing ISO 14000. Irwin Professional Publishing, Chicago, Illinois. 500 p.

Viana, V.M., J. Ervin, R.Z. Donovan, C. Elliott and H. Gholz (eds.). 1996. Certification of Forest Products: Issues and Perspectives. Island Press, Covelo, California. $271 \mathrm{p}$.

Vogt, K., B. Larson, J. Gordon, D. Vogt and A. Fanzeres (eds.). 1999. Forest Certification: Roots, Issues, Challenges and Benefits. CRC Press, Boca Raton, Florida. 400 p.

Wilson, B. and S. Wang, 1999. Sustainable forestry: the policy prescription in British Columbia. In A. Yoshimoto and K. Yukutake (eds.). Global Concerns for Forest Resource Utilization: Sustainable Use and Management. Kluwer Academic Publishers, London, UK. 35-45. 